\title{
Perception of White-Collar Criminality: an Online Exploratory Survey Among Students in Azerbaijan
}

\section{Inqilab SHAHBAZOV ${ }^{1}$ (), Zaur AFANDIYEV ${ }^{2}$ ()}

${ }^{1}$ Baku State University, Social Work and Psychology Faculty, Baku, Azerbaijan ${ }^{2}$ Social Research Centre, Public Opinion Survey Department, Baku, Azerbaijan

ORCID: I.S. 0000-0002-4184-4539; Z.A. 0000-0002-8766-9772

\section{ABSTRACT}

Recent studies have challenged traditional wisdom regarding public indifference to white-collar crime by revealing equal or greater perceived seriousness of these crimes among respondents relative to traditional crime. The first of its kind in the local context, this study examined perceptions of white-collar crime among a self-select sample of students $(n=301)$ at Baku State University in Azerbaijan. The results indicate that, overall, Azerbaijani students view white-collar crimes as more serious than traditional crimes. Specifically, the manipulation of evidence by police officers, the acceptance of a bribe by a government minister, and an accountancy firm representing a large corporation hiding evidence of tax fraud from inspectors were ranked by the overwhelming majority as more serious than the street crimes they were compared with. Nonetheless, in some scenarios, both crime types were deemed equally serious. Binomial tests for comparison of the proportion of answers in each crime scenario, as well as Mann-Whitney $\mathrm{U}$ to allow for comparing mean differences in perceived seriousness and punitiveness were employed. Limitations of the study and suggestions for future research are discussed in the end.

Keywords: White-collar crime, perceptions of white-collar crime, seriousness of crimes, Azerbaijan 


\section{Introduction}

The current literature on perceptions of white-collar crime is predominantly made up of studies conducted in economically more developed parts of the world, such as the US, England, Australia, and Canada (Friedrichs, 2007; Nelken, 2002). In the globalised world, there is a growing need to explore different aspects of white-collar crimes cross-culturally (Friedrichs, 2007). As highlighted by Friedrichs (2007), both the characteristics and perceptions of white-collar crime differ between jurisdictions. Considering the cultural, political, historical, and economic differences between Azerbaijan and the aforementioned countries, this study has the potential to uncover different attitudes to white-collar crimes in a distinctly non-Western context.

\section{White-collar Crime}

The term white-collar crime is defined as "a crime committed by a person of respectability and high social status in the course of his occupation" (Sutherland, 1983, p. 7). Phrased differently, it is a crime committed by a person in an occupation with the intent to make a material gain or achieve an organisational goal (Benson \& Simpson, 2014; van Erp, Huisman and Vande Walle, 2015). White-collar crime can occur in at least two forms - commission and omission (Croall, 2001). While the former refers to the deliberate execution of an illegal act, the latter entails the harmful acts arising from the negligence of laws and rules on the part of the entity.

The general public has historically demonstrated different attitudes towards traditional crimes and the crimes of men in the suit. As succinctly noted by (Croall, 2001, p.1), "'it is not common, for example, to hear demands for 'zero tolerance' of fraudsters or antisocial behaviour orders for companies", which indicates a rather permissive attitude of the public towards white-collar crimes and tougher perception of street crimes. Such permissive attitude, as suggested by Martinez (2014), may also have been fuelled by the romanticisation of white-collar crime by the current culture of TV, which is in stark contrast to the portrayal of street crimes. However, white-collar crime is gaining increasing levels of attention in the public over recent decades, largely due to global events such as the economic crisis in 2007-08 (Cullen, Hartman, \& Jonson, 2009; Rosoff, Pontell \& Tillman, 2010), which have contributed to a shift in perceptions regarding this particular category of crime.

Exploring public opinion on the wrongdoings of the people and organisations in power is interesting from multiple perspectives. While gauging public perception is of interest 
from a criminological perspective, having an understanding of the public attitude towards white-collar crime can provide valuable information to public officials and policymakers (Piquero, Carmichael, \& Piquero, 2007). Given the importance of informal control in addition to formal oversight by official institutions exercised on organisational entities, it is worth exploring how ordinary citizens perceive their wrongdoings (Hamilton \& Sanders, 1976). Furthermore, in terms of policy implications, Piquero, Carmichael, \& Piquero (2007) highlight that public sentiments have the potential to shape both the crime control policy of the state and legislative reactions to crime and punishment.

\section{Literature Review}

From a historical point of view, white-collar crime rarely caught the public's attention until a few decades ago (Geis, 1973). In general, the tendency was that crimes resulting in direct bodily harm were usually perceived as the most serious offences (see Rossi, Waite, Bose and Berk, 1974; Grabowsky, Braithwaite, and Wilson, 1987; O’Connell and Whelan, 1996). However, the findings of more recent studies signal a hardening of public attitudes towards white-collar criminals. Despite the rating being inconsistent across the different types of white-collar crime (Albanese, 1995; Cullen, Clark, Mathers, \& Cullen, 1983; Goff \& Nason-Clark, 1989), more and more studies report increased attention to white-collar offences as the public perceives them as at least as serious as ordinary offences (Calavita, Pontell and Tillman, 1997; Kane \& Wall, 2006; Piquero, Carmichael, \& Piquero, 2007). For instance, a study conducted by Cullen, Clark, Link, Mathers, Niedospial and Sheahan, 1985) concluded that particular types of white-collar crime (i.e. producing unsafe goods, vending contaminated groceries, embezzlement) were considered more serious than armed robbery, burglary, and arson (Cullen et al. 1985). Using the randomly collected dataset from the National White Collar Crime Center in 1999, Piquero, Carmichael, \& Piquero (2007) analysed the data to compare the perceived seriousness of the white-collar crime and street crime. The authors concluded that the white-collar crimes in the dataset are perceived as equally or more serious than street crimes. Similarly, Dodge, Bosick \& Antwerp's (2013) survey among 900 Colorado residents revealed that white-collar crime and traditional offences were ranked equally serious. The survey focused particularly on white-collar crimes such as Ponzi schemes, which were seen as more serious than the three street crimes (auto theft, burglary, prostitution) presented to respondents. On a larger scale, the National White Collar Crime Center conducted research in 2005 to measure the public perception 
of white-collar crime seriousness (Kane \& Wall, 2006). A telephone survey of 1,605 households selected randomly across America revealed that, on a scale of one to seven, respondents rated white-collar crime nearly equal to the traditional crime. The analysis also revealed that crimes involving physical harm, crimes committed by organisational offenders, and crimes perpetrated by high-status individuals were perceived as more serious than their respective counterparts.

Considering the non-Western context of Azerbaijan, it is worth reviewing the literature on the countries with greater similarities to Azerbaijan. A study by Sever and Roth (2012) exploring public perceptions of white-collar crime in Turkey, a neighbouring country with significant similarities to Azerbaijan, reported that Turkish citizens considered white-collar crime nearly as serious as traditional crimes. Measuring crime seriousness across 13 offences, the authors noted that, in comparison to Americans, Turkish citizens attached relatively lower seriousness to white-collar offences versus traditional crimes. Sever and Roth attributed Turkish public attitude to a number of factors, such as a comparatively lower level of awareness and very limited media coverage of white-collar offences. More recently, Benk, McGee, and Budak (2018) measured Turkish citizens' perception of the severity of bribery relative to other crimes and violations. Administered to 545 Turkish respondents, the survey revealed that bribery ranked 16th among the 33 offences surveyed, located in the middle of the continuum of seriousness. According to the conclusion of the authors, bribery was not perceived as a very serious crime by Turkish respondents. While this offence received a significantly lower score compared to violent crimes, arson, and carjacking, as well as embezzlement, it was, however, ranked higher than offences such as shoplifting and bike theft. In Iran, Azerbaijan's southern neighbouring country, a survey of a randomized sample of 1,522 students selected from 20 universities around the country found that although sexual offences were rated as the most serious (mean score of 0.92), economic and environmental offences earned a high mean score as well (mean score of 0.82). Finally, a study by Sebba (1983) in Israel among new immigrants from the Soviet Union found that those with stronger exposure to Soviet culture and with longer living experience in the Soviet Union held tolerance towards white-collar crime, and likely to perceive them as not serious.

\section{Azerbaijan's Context}

Azerbaijan is situated in the South Caucasian region, and it is an oil-rich, economically developing country. It regained its independence from the Soviet Union in 1991 after 
nearly 70 years. Since its independence, the government has made significant investments in its state institutions and the public sector in order to transform the country, with a population of fewer than 10 million people, from a Soviet relic into a modern nation. In the immediate years after the breakdown of Soviet rule, the country was thrown into political, social and military turmoil, as a result of which public security became one of the most pressing concerns (de Waal, 2013). However, once the order was restored with the establishment of the new state and agreement of the ceasefire, coupled with the exploration of large oil reserves, the country rapidly developed both socially and economically. GDP skyrocketed from US\$4.9 billion to US\$74 billion from 1992 2013 (The World Bank, 2018), and the Human Development Index for the country improved from 0.612 to 0.757 from 1995-2017 (United Nations Development Programme, 2018).

\section{White-collar crime in Azerbaijan}

White-collar crime occurs in every country around the world, albeit in a different fashion and on a different scale. Like in many other countries, there is no separate data on the extent of white-collar crime in Azerbaijan. Nonetheless, the data on a number of white-collar crimes is available, which could provide insights into the dynamics of this crime category. According to the data from the State Statistics Committee (2017), the number of recorded economic crimes - one of the white-collar crimes has greatly fluctuated over the years. Thus, while the figure was 2,136 in 1995, it declined significantly to 491 in 2005 before rising to 2,553 in 2017 . Nearly half (46.9\%) of these crimes in 2017 involved tax evasion, with illegal smuggling of goods accounting for $35.3 \%$. The number of convicted offenders for the year 2017 for economic crimes stood at 428 (the conviction rate of $16,7 \%$ ).

Generally speaking, burglary/theft, drug crimes and the violation of traffic rules were the three most recorded offences at least in the last decade (Statistics Committee, 2017). If one divided crimes under the categories of property crime and personal violent crime, the following offences are categorised as violent crimes in the official data on crime: murder, intentional assault resulting in physical injury, torture and creating a dangerous situation. The following offences are categorised as property crimes: burglary, robbery, fraud, embezzlement, theft. Historically, while violent crimes have generally fluctuated, property crimes have increased. The latest data available at the time of writing suggests that the aggregate crime rate per 1,000 population in 
Azerbaijan stood at 2,35 in 2017. As of 2017, the national population size was 9,810,000. Property crime $(0.8$ per 1,000$)$ fraud $(0.3$ per 1,000$)$ and illegal possession of drugs $(0.29$ per 1,000$)$ were the most prevalent crimes in the country. While property crime was the most prevalent crime in the country $(2,792$ - burglary, robbery and larceny all combined), 684 violent crimes ( 0.07 per 1,000; murder/attempted murder, assault and rape/attempted rape all combined) were recorded in 2017. In terms of victims of crime, 6,830 people were either wounded or killed in 2017.

Though not reflected by the official crime data, corruption has long been widespread in the country, though the government has taken important steps to eradicate it. Politically, according to the Democracy Index produced by the Economist Intelligence Unit, the level of democracy in Azerbaijan is significantly lower relative to most of the countries where fear of crime has been examined (The Economist, 2019). Despite the significant improvement, Azerbaijan ranked 126 out of 180 countries in terms of the level of transparency and corruption (Transparency International, 2019). Given that white-collar offences must be discovered by proactive means undertaken by criminal justice forces (Pontell \& Geis, 2007), one may speculate that the actual number of white-collar crimes in the country may be much higher. Coupled with total state control of the statistics, the implication is that finding unbiased accounts of upperworld criminal activities is extremely difficult in Azerbaijan.

There have been a small number of studies examining public perception of some white-collar crimes, bribery and corruption in particular. Sadigov (2018) conducted a face-to-face survey among 1,002 people in Azerbaijan in 2015, finding that the local circumstances largely shaped respondents' perception of corruption. That is certain technically illegal behaviours that would constitute an act of bribery may well be perceived as an act of expression of gratification and respect by citizens to public servants. For instance, offering informal payments to facilitate faster document processing was not seen as an illegal act by the majority of the respondents. Instead, it was viewed as an act of respect towards public officials. Thus, certain behaviours that are technically illegal may not be seen as corrupt by Azerbaijani people, an attitude that regularly initiates bribery. The author concludes that the citizens of Azerbaijan actively participate in corruption, often acting as initiators of bribes to those in authority. In another study of bribery and corruption in Azerbaijan, Sadigov (2014) explored this problem within the sphere of the higher education system. His findings are revealing in terms of public perception of this particular type of white-collar crime in the local 
context. Although there are many instances in which educators or professors ask for a bribe, for example, to award higher exam grades to students, a significant proportion of the students are actively involved in offering bribes. Not only do they, on average, offer more bribes than are asked for one by their educators, but also almost half of the students $(47.3 \%)$ in this study admitted "witnessing their peers offering bribes to their educators on a regular basis" (Sadigov, 2014, p. 51). In general, it was found that $67.3 \%$ of the students had bribed their educators. As a motive, the desire to get through courses in a relatively easier way, obtaining higher grades with minimal effort, and avoiding boredom associated with studying were some of the most commonly cited reasons. This finding implies that so long as it satisfies their needs, this group of people may actively engage in bribery within the educational sphere.

The attitude of private sector enterprises towards corruption and bribery in Azerbaijan has also been explored. From the perspective of private sector entities, procedures such as obtaining business licenses, certifications, and loans are sometimes met with demands for bribes, which are then paid by private companies to keep their business going (Bertelsman Stiftung, 2018). As reported by Lee, Frank, Wadsworth \& Brenda (2017) analysis of Business Environmental and Enterprise Performance Survey data from studies in 2002, 2005, and 2009, 52\% of Azerbaijani firms in 2009 reported an informal gift/payment expectation or request for permit applications. In this environment where businesses have a high chance of engaging in bribery, Sadigov (2014) explored the extent to which businesses were willing to participate in bribery and their perception of it. Conducted among small and medium-sized enterprises (SME), it was found that "Azerbaijani SMEs offer bribes slightly more frequently in comparison to bribe demands that they are facing from bureaucrats" (Sadigov, 2014 , p. 35). Rather interestingly, although 53.4\% of the entrepreneurs perceived corruption as the most important problem that businesses face in Azerbaijan, they nonetheless paid bribes even though $63.7 \%$ had a real choice to avoid them. The same study also revealed that despite the frequency of engaging in bribery, a mere $0.8 \%$ of the entrepreneurs expressed fear of the legal consequences of offering a bribe to a public servant (Sadigov, 2014). From a perception point of view, this study implies that despite seeing corruption as a serious impediment to the development of business, entrepreneurs themselves were willing to offer bribes to advance their business interests. In other words, instead of perceiving bribery as a white-collar crime to avoid, Azerbaijani entrepreneurs viewed it more as an instrument to expedite business-related procedures and ultimately increase their profit. 
This study represents the first attempt to measure the perception of Azerbaijanis towards several white-collar and street crimes. Specifically, due to a lack of resources and funding, this survey explores the perception among students at one local university. Thus, the findings of this study are mostly indicative, not representative. Nonetheless, being the first study of its kind, it provides some useful insights into how Azerbaijani students view white-collar and street crimes in terms of their seriousness.

\section{Methodology}

\section{Sampling}

Adopting a non-random sampling strategy, a self-select sample of students (both undergraduate and postgraduate) from Baku State University was used. This study divided the sample into two subgroups - law and criminology students and non-law students. The division of the sample was intentional since the authors were also interested seeing whether the views of law and criminology students differ from non-law students. The law and social science departments were contacted to provide access to the emails of the students. However, the authors of this study do not claim that the findings are representative of the general population of Azerbaijan. Rather, it is indicative.

The choice of a student body as the sampling unit was based on numerous theoretical and practical grounds. A number of different studies had demonstrated that students are appropriate for attitudinal research and theory testing (Austin \& Hummer, 1994; Gibbs, Giever, \& Higgins, 2003). One of the few social groups with a much greater likelihood of having an in-depth understanding of this issue is students. Not only is white-collar crime taught at universities, but the students, particularly those enrolled at humanities courses, have a greater probability than others to explore the issues and concepts related to this topic. Students at humanities and law courses are more likely than other groups of people to explore crime in-depth within their curriculum. In our opinion, they have the necessary sense, knowledge, and capacity to identify and understand white-collar crime and the relevant issues, thus making them more prepared and willing to participate in our survey. From a practical point of view, the choice of the student body as the sampling unit was seen viable due to lack of funding and limited resources.

Two of the authors employed at the Baku State University contacted the administrators of the courses at humanities departments to gain access to the emails of the students. For access to the sample, the administrators of the courses required an initial discussion of the questionnaire. In response to the request, the questionnaire was verified face to 
face to assure that no indelicate question had been included, though no modification was required by the institution. The subsequent stage involved recruitment. Students from the courses were recruited via email, which contained a link to a web-based survey containing the questionnaire. Participation in the survey was voluntary. No personal information was requested or recorded. All the responses were anonymous and confidential. The survey remained open between 15 September and 14 October 2018.

The response rate was 303. Eliminating incomplete responses as well as those completed too quickly (the system showed that average completion time was about 4 minutes) yielded a final sample of 301 participants. While $76.4 \%$ of the respondents were bachelor students, the remaining $23.6 \%$ were postgraduate students. The median age was 21 years and the ages ranged from 17 to 60 . Other variables of the students are shown in Table 1. Since the data collection method involved self-selection, the authors of this study do not claim that the findings are representative of the whole student population in the country.

Table 1. Demographic profile of the survey respondents $(n=301)$

\begin{tabular}{|l|c|c|}
\hline & Number of respondents & Percentage of respondents (\%) \\
\hline Gender & 195 & 64.8 \\
\hline Fale & 106 & 35.2 \\
\hline Age & & 48 \\
\hline 17 to 21 years & 143 & 22 \\
\hline 22 to 25 years & 66 & 30 \\
\hline 26 and over & 92 & \\
\hline Household income & & 12 \\
\hline $0-250$ AZN & 36 & 17 \\
\hline $251-400$ AZN & 50 & 19 \\
\hline $401-600$ AZN & 57 & 14 \\
\hline $601-800$ AZN & 42 & 16 \\
\hline $801-1,000$ AZN & 49 & 22 \\
\hline 1,001 AZN + & 64 & 76.4 \\
\hline Education & & 23.6 \\
\hline Undergraduate & 230 & 64 \\
\hline Postgraduate & 71 & 8 \\
\hline Area of residence & & 20 \\
\hline City & 192 & 8 \\
\hline Suburbs & 23 & 33.5 \\
\hline Province & 60 & 66.5 \\
\hline Rural & 23 & \\
\hline Course & 101 & \\
\hline Law and criminology & 200 & \\
\hline Others (non-law) & \multicolumn{2}{|c|}{} \\
\hline
\end{tabular}




\section{Survey instrument}

Two general crime categories are covered by the current survey - white-collar crime and street crime. While the former has been defined above, the latter is defined as a term entailing crime occurring in public space that results in violent or monetary loss to a victim.

To gauge public opinion on white-collar crime, the most prevalent method has been to present subjects with a list of crimes and ask them to rank them based on the seriousness or to assign a seriousness score to each crime. The current study is not an exception. The survey employed in this study was created by the authors themselves for purpose.

The survey asked a sample of students to consider two types of conduct and then state which type of behaviour they regarded as more serious. Respondents also had an option to assign an equal degree of seriousness to both crimes presented in each scenario. Each question contrasted an example of white-collar crime and misconduct with an example of traditional crime. The list of traditional crimes and white-collar crimes used in scenarios is presented in Table 2.

The rationale behind choosing these items, particularly white-collar crimes, stemmed from the local crime landscape of Azerbaijan. As noted above, tax evasion, fraud and corruption or bribery are some of the most widely prevalent offences in the country. Regarding street crimes, theft has consistently been the most recorded crime in Azerbaijan in recent years.

\section{Data collection method}

The announcement for participants was announced between March and May of 2018 via the social media platform Facebook. ${ }^{1}$ More precisely, the link to the survey was placed on three media agencies' Facebook pages ${ }^{2}$. At the time of the study, the total number of followers of these pages stood at around 300,000. However, there is no information as to the types of people that might be following these accounts, which is acknowledged by the authors as one of the limitations of this survey.

1 As of September 2018, there were 1854000 Facebook users in Azerbaijan on September 2018, which accounted for $18.4 \%$ of the entire population. At the time of the data collection (March 2018), Facebook occupied first place among users of social media according to popularity. It had the $29 \%$ share of the social media market in Azerbaijan (ONA News Agency, 2019)

2 These media agencies - APA Information Agency, Lent News Agency and Vesti News Agency were chosen primarily due to their large audience. While APA's website is visited by around 150-200,000 people daily, this number stands at 330-400,000 and 550-600,000 for Lent.az and Vesti.az respectively. 
An online survey was adopted for data collection. Considering the issues with freedom of speech without fear of retaliation in Azerbaijan (Council of Europe, 2019) and sensitive nature of the subject (as noted by Huisman \& Vande Walle (2010) Goldstein (1974), some white-collar crimes can be committed by government officials, judiciary and law enforcement bodies), the authors believed that unobtrusive survey method is the most suitable approach from respondents' point of view. The choice of the self-report survey was further supported by what Côté (2013) speaks of regarding countries like Azerbaijan. That is, according to Côté, in politically sensitive regions such as the former Soviet Union anonymity and privacy protection are of paramount importance for respondents. Similarly, since self-report surveys have been associated with reductions in socially desirable responses and with an increased willingness to answer sensitive questions (Kelly, Harper, \& Landau, 2008), it was considered suitable to explore the views of students on the highly sensitive issue of white-collar crime. Another key benefit of this data collection method was the efficiency it provided, along with a higher coverage rate. Conducting a face-to-face survey with 301 students during the day when they have lessons could have been more time-consuming, and inconvenient to students, whereas completing the survey in their free time gave them ample time to think and reflect before answering each question. The survey was set in such a way that respondents would not be able to complete more than one. The survey was located on the Survey Monkey platform, which was accessible through a link sent in emails to the students.

Table 2. Types of crimes presented in the scenarios

\begin{tabular}{|c|c|c|}
\hline Scenario & White-collar crimes & Street crimes \\
\hline 1 & Evidence manipulation by the police & $\begin{array}{c}\text { A shoplifter stealing goods from a } \\
\text { supermarket }\end{array}$ \\
\hline 2 & $\begin{array}{l}\text { An accountancy firm representing a large } \\
\text { corporation hiding evidence of tax fraud } \\
\text { from inspectors }\end{array}$ & $\begin{array}{c}\text { A shoplifter stealing goods from a } \\
\text { supermarket }\end{array}$ \\
\hline 3 & Overcharging for essential medicine & Joyriding \\
\hline 4 & $\begin{array}{l}\text { A minister's acceptance of a bribe to } \\
\text { influence government policy }\end{array}$ & Joyriding \\
\hline 5 & $\begin{array}{c}\text { A minister's acceptance of a bribe to } \\
\text { influence government policy }\end{array}$ & $\begin{array}{l}\text { Someone knowingly handling } \\
\text { stolen goods }\end{array}$ \\
\hline 6 & $\begin{array}{l}\text { Deliberate defrauding of customers by a } \\
\text { bank }\end{array}$ & $\begin{array}{l}\text { Someone knowingly handling } \\
\text { stolen goods }\end{array}$ \\
\hline 7 & $\begin{array}{c}\text { Manipulation of stock prices by an } \\
\text { investment firm }\end{array}$ & $\begin{array}{l}\text { Someone knowingly handling } \\
\text { stolen goods }\end{array}$ \\
\hline
\end{tabular}




\section{Results and Findings}

\section{Descriptive statistics}

All scores were combined to determine a response average. To note, the scores for the mean score ranged from -1 to 1 . The closer to 1 score is, the more serious a white-collar crime is perceived, and vice versa. It revealed a mean (x) seriousness score of $\mathrm{x} 0.551$ indicating the majority of students viewed the represented whitecollar crimes as serious. Figure 1 shows the mean seriousness rating of each crime scenario presented in the survey. The scenario involving the comparison of manipulation of evidence by the police and shoplifting produced the highest seriousness mean score (x 0.902) for a white-collar crime whereas the scenario comparing the manipulation of stock price to knowingly handling stolen goods received the lowest seriousness mean score for a white-collar crime presented (x 0.230). Overall, one can say that the scenarios involving white-collar and traditional crime were fairly dispersed in terms of seriousness ratings. There was no accumulation on the top or bottom of the list for either type of offense.

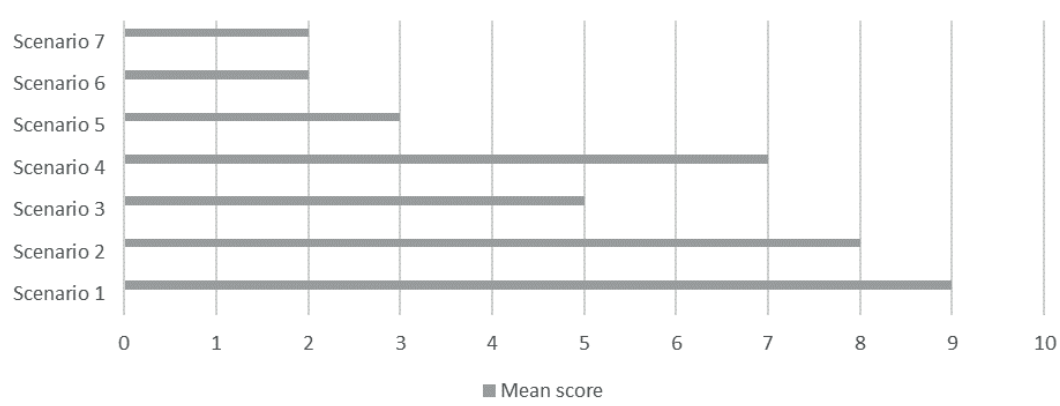

Figure 1. Average crime seriousness scores for each scenario ( $\overline{\mathbf{x}})$

Table 3. Results of the scenarios (shown in \%)

\begin{tabular}{|l|c|c|c|c|c|c|c|}
\hline & Sce. 1 & Sce. 2 & Sce. 3 & Sce. 4 & Sce. 5 & Sce. 6 & Sce. 7 \\
\hline White-collar crime is more serious & 91 & 81 & 65 & 81 & 46 & 41 & 38 \\
\hline Street crime is more serious & 2 & 5 & 12 & 4 & 12 & 16 & 17 \\
\hline Both are equally serious & 5 & 9 & 23 & 14 & 41 & 43 & 37 \\
\hline No idea & 2 & 6 & 0 & 1 & 1 & 0 & 8 \\
\hline
\end{tabular}


Table 4. Summary of demographic characteristics influencing individuals' crime seriousness scores

\begin{tabular}{|l|c|c|c|c|c|c|c|}
\hline & Sce. 1 & Sce. 2 & Sce. 3 & Sce. 4 & Sce. 5 & Sce. 6 & Sce. 7 \\
\hline Gender & - & - & - & - & - & - & - \\
\hline Income & - & - & - & - & - & - & - \\
\hline Area of residence & - & $*$ & - & - & - & - & - \\
\hline Age & - & - & - & - & - & - & - \\
\hline Education level & - & - & $*$ & - & - & $*$ & - \\
\hline Field of education (law and non-law) & - & - & - & $*$ & - & - & $*$ \\
\hline$* * \mathrm{P} \leq 0.01 ; * \mathrm{P} \leq 0.05$ & \multicolumn{7}{|l|}{} \\
\hline
\end{tabular}

The binomial test was conducted to allow for a comparison of the numbers of participants who chose different responses in viewing which crime is more serious in each 7 crime scenarios. For all 7 crime scenarios, it was revealed that significantly more respondents perceive white-collar crime as more serious than street crime (see Table 3), but there were no significant differences between the number of participants who view whitecollar crime more serious and the number of participants viewing both crimes as equally serious in all presented crime scenarios (see Table 4). Across the scenarios 5 , 6 and 7 there is no significant difference in the number of participants seeing whitecollar crime more serious and the number of participants regarding both crimes on the same level of seriousness (see Table 4).

Table 5. The results of the Mann-Whitney $U$ test on previous victimisation and its relationship with each scenario

\begin{tabular}{|l|c|c|c|c|c|c|c|}
\hline & Sce. 1 & Sce. 2 & Sce. 3 & Sce. 4 & Sce. 5 & Sce. 6 & Sce. 7 \\
\hline Fraud in the last 12 months & - & - & - & $*$ & - & $*$ & - \\
\hline $\begin{array}{l}\text { Request by a company for unneces- } \\
\text { sary repair in the last 12 months }\end{array}$ & - & - & - & & & - & $* *$ \\
\hline $\begin{array}{l}\text { Product pricing fraud in the last 12 } \\
\text { months }\end{array}$ & - & - & - & - & - & - & - \\
\hline $\begin{array}{l}\text { Suffering from the consequences of a } \\
\text { large corporate crime or scandal in the } \\
\text { last 12 months }\end{array}$ & - & $*$ & - & - & - & - & $*$ \\
\hline $\begin{array}{l}\text { Credit card hacker attack in the last 12 } \\
\text { months }\end{array}$ & - & - & - & - & - & - & - \\
\hline$* * \mathrm{P} \leq 0.01 ; * \mathrm{P} \leq 0.05$ & & & & & & \\
\hline
\end{tabular}


Table 6. Binominal tests for comparison of the proportion of answers in each crime scenario

\begin{tabular}{|l|l|l|l|l|l|l|l|}
\hline & Sce. 1 & Sce. 2 & Sce. 3 & Sce. 4 & Sce. 5 & Sce. 6 & Sce. 7 \\
\hline $\begin{array}{l}\text { The occurrence of answer "White-collar } \\
\text { crime is more serious" }\end{array}$ & 275 & 244 & 196 & 245 & 138 & 130 & 114 \\
\hline $\begin{array}{l}\text { The occurrence of an answer "Both } \\
\text { crimes are equally serious" }\end{array}$ & 15 & 26 & 68 & 42 & 124 & 124 & 112 \\
\hline $\begin{array}{l}\text { Occurrence of answer "Street crime is } \\
\text { more serious" }\end{array}$ & 7 & 14 & 36 & 11 & 36 & 47 & 50 \\
\hline $\begin{array}{l}\text { Sig. of test ("White collor crime" and } \\
\text { "street crime") }\end{array}$ & 0,00 & 0,00 & 0,00 & 0,00 & 0,00 & 0,00 & 0,00 \\
\hline $\begin{array}{l}\text { Sig. of test ("White collor crime" and } \\
\text { "Both crimes are equally serious") }\end{array}$ & 0,00 & 0,00 & 0,00 & 0,00 & 0,42 & 0,75 & 0,95 \\
\hline
\end{tabular}

\section{Bivariate Analyses}

In bivariate analyses, Mann-Whitney $U$ test was used to allow for comparing mean differences in perceived seriousness and punitiveness in all 7 scenarios between groups created according to the respondents' gender, level of education (undergraduate and postgraduate), field of education (law and non-law) household income, area of residence, and age (see Table 5). Previous white-collar victimisation was also explored to see whether it has an effect on the respondent's perception of crime. However, only the findings achieving statistical significance are reported. The results of the tests for each variable are shown in Table 4 . While an asterisk $(*)$ means a statistically significant relationship between a variable and the respondents' crime perception at the level of $\alpha 0.05$, variables denoted with a double asterisk (**) translate to a stronger relationship at the level of $\alpha 0.01$.

Overall, the analysis revealed the absence of a statistically significant difference in the perceived seriousness of given crimes between compared groups in many scenarios. However, between respondents with different field of education was significant difference in perception of the crimes presented in Scenario $4(\mathrm{p}<.05)$ and Scenario $7(\mathrm{p}<.05)$, which, respectively, compared the acceptance of a bribe by a government minister to influence government policy to joyriding and manipulation of stock prices to knowingly handling stolen goods. More precisely, more of those with law education tended to view these white-collar crimes more seriously than non-law students. Respondents' area of residence was a statistically significant variable $(\mathrm{p}<.05)$ for the Scenario 2 (the concealment of tax from tax authorities by an accountancy firm representing a corporation and shoplifting from a supermarket), while level of education 
made a difference between respondents' perception of crime seriousness for the crimes shown in Scenario 3 (overcharging for essential medicine by a pharmaceutical company) and Scenario 6 (deliberate defrauding of customers by a bank). For both scenarios, the value of significance was $\mathrm{p}<.05$, meaning that more undergraduate students view these white-collar crimes more seriously.

In terms of the previous victimisation of respondents, there were variations in perceptions of crimes between victims of some crimes and non-victims in a handful of scenarios. The strongest difference $(\mathrm{p}<.01)$ was observed between Scenario 7 and a respondent's previous victimisation by a company requesting unnecessary repair in the last 12 months. Phrased differently, those suffering from this type of white-collar victimisation were more likely to perceive street crime - knowingly handling of stolen goods more seriously than the white-collar crime presented. There was a statistically significant difference between being the victim of fraud and respondents' response in Scenario 4 $(\mathrm{p}<.05)$ and Scenario $6(\mathrm{p}<.05)$. Suffering from consequences of a large corporate crime or scandal in the last 12 months was significantly correlated with the perception of crimes presented in Scenario 7. Those suffering from the consequences of a large corporate crime or scandal in the last 12 months were more likely to perceive knowingly handling of stolen goods more seriously than manipulation of stock price.

Table 7. Victimisation of respondents

\begin{tabular}{|c|c|c|c|c|c|}
\hline $\begin{array}{c}\text { Previous } \\
\text { victimisation }\end{array}$ & $\begin{array}{c}\text { Fraud in } \\
\text { the last 12 } \\
\text { months }\end{array}$ & $\begin{array}{c}\text { Request by a } \\
\text { company for } \\
\text { an unnecessary } \\
\text { repair in the } \\
\text { last 12 months }\end{array}$ & $\begin{array}{c}\text { Product } \\
\text { pricing } \\
\text { fraud in } \\
\text { the last 12 } \\
\text { months }\end{array}$ & $\begin{array}{c}\text { Suffering from } \\
\text { consequences of } \\
\text { a large corporate } \\
\text { crime or scandal in } \\
\text { the last 12 months }\end{array}$ & $\begin{array}{c}\text { Credit card } \\
\text { hacker attack } \\
\text { in the last 12 } \\
\text { months }\end{array}$ \\
\hline Yes & $24 \%$ & $8 \%$ & $54 \%$ & $32 \%$ & $5 \%$ \\
\hline No & $76 \%$ & $92 \%$ & $46 \%$ & $68 \%$ & $95 \%$ \\
\hline
\end{tabular}

\section{Discussion and Conclusion}

Our study was the first attempt to explore the perception of white-collar crimes in Azerbaijan, albeit its focus was students at one university. Despite the issues with the sampling, the results are mostly in line with many findings observed abroad: the students surveyed generally perceive white-collar crime to be at least as serious as and in some cases, more serious than - traditional crimes. The average mean score of $\overline{\mathrm{x}} 0.551$ testifies to the seriousness Azerbaijani students assign to white-collar crimes. 
Moreover, for all 7 crime scenarios, binominal tests revealed that significantly more respondents perceive white-collar crime more seriously than street crime. The ratings across all scenarios ranged from a mean score of $\bar{x} 0.902$ to $\bar{x} 0.23$. None of the scenarios produced a mean score of below 0 , which would indicate street crime being perceived more seriously than white-collar crime.

The scenario comparing police manipulation of evidence and shoplifting from a supermarket generated a widespread agreement that the former is more serious than the latter $(\overline{\mathrm{x}} 0.90)$. Our finding may arise from the idea that while shoplifting by an individual may be motivated by an urgent need for making ends meet on the part of the offender, police manipulation of evidence amounting to the obstruction of justice is likely a calculated act. Alternatively, the students may understand the severity of the implications (i.e. erosion of public trust in the police) of police manipulation of evidence, which may have encouraged them to attach higher seriousness score to this white-collar crime. Coupled with a relatively corrupt public perception of the police (Transparency International, 2018), our finding is an anticipated one.

In the second scenario, the overwhelming majority of the respondents considered the behaviour of the accountancy firm more serious than shoplifting from a supermarket $(\bar{x} 0.80)$. Such an attitude may be due to the pervasiveness of tax evasion in the country. According to the official data on economic crimes, nearly half (46.9\%) of economic crimes in 2017 involved tax evasion, an indication of the relatively large scale of this particular white-collar crime. Thus, it is possible that the students surveyed, well aware of the implications of tax evasion by companies, condemn this behaviour more strongly than shoplifting. Furthermore, since tax evasion is mostly a premeditated act, the consequences of which for the public budget are known by a perpetrator, the respondents surveyed may have assigned a greater degree of seriousness to this misconduct due to this particular aspect. On the other hand, shoplifting may be caused by an impulse arising from a personal need, and its repercussions are unlikely to equal those of tax evasion. Another potential explanation is that the students surveyed may have been aware of the potential implications of the tax evasion for the public budget in the form of lost tax revenue.

The next item on the questionnaire presented the scenarios of the $2,000 \%$ overcharge of the Ministry of Healthcare for an essential drug by a pharmaceutical company and joyriding. Though producing a relatively lower mean score than previous scenarios $(\overline{\mathrm{x}} 0.53)$, a sizeable proportion of the students perceived the conduct of the former 
more serious than the latter. The exact reasons behind this attitude remain obscure, but it may be because of the structural problems of the national healthcare system and the problems that users experience. In a country where the healthcare service is not always free, hospitals frequently charge patients and drugs are sold commercially (The Institute for War \& Peace, 2016), the implications of such white-collar crime are severe, particularly for low-income patients. Regarding drugs, one study noted that the affordability of medicine is an issue for local patients (Papiashvili \& Orugova, 2013). Coupled with absence of mandatory health insurance as of the time of the writing, an ordinary Azerbaijani citizen was likely to suffer from high drug prices. Taking these problems into consideration, it is not impossible for the students surveyed, to understand the repercussions of overcharged prices of medicines, which led most of them to perceive this particular white-collar crime as more serious.

The scenario involving the comparison of the acceptance of a bribe by a government minister to influence government policy and a joyrider was particularly relevant to the local context due to the pervasiveness of corruption in some government agencies. A significant majority of the students $(81 \%)$ in the survey viewed the behaviour of the official as more serious than a joyrider ( $\bar{x} 0.78)$. In a country where some high-ranking public officials, including ministers, have been imprisoned or removed from the office on corruption charges, an official's acceptance of a bribe is a matter expected to be viewed seriously by the general public. Obviously, Azerbaijani respondents, aware of the repercussions of corruption and bribery, perceived an official's acceptance of a bribe to influence government policy to be more serious than the behaviour of a joyrider, whose conduct is less likely to have any kind of social harm. It may also be inferred that respondents surveyed are less likely to show tolerance towards individuals who abuse their status to commit a crime. In the words of Friedrichs (2007), they are perceived as "trusted criminals" since they violate the trust granted to them for service.

However, when the same behaviour of a government minister was compared to someone knowingly handling stolen goods in Scenario 4, the students were more equally divided in terms of how serious they perceived each crime. That is, only $46 \%$ viewed the white-collar offence as more serious than the handling of stolen goods, and the proportion of the students regarding these crimes as equally serious was $41 \%$ ( $\bar{x} 0.34)$. By comparison, only $14 \%$ of the respondents saw an official's acceptance of a bribe to influence government policy and joyriding as equally serious. The potential explanation for the assignment of an equal degree of seriousness to the two crimes - the acceptance 
of a bribe and handling stolen goods may be due to the ultimate result of both acts. That is, in both offences, the offender earns ill-gotten gains, which may have triggered the respondents to see both acts as equally serious. This was a scenario where the respondent's field of education was significantly related to the perception of the crimes presented. Phrased differently, more law and criminology students view this particular white-collar crime more seriously than the counterpart crime. This difference may be explained, in part, by the deeper and better awareness of law and criminology students than other students of the consequences of ministerial corruption, since the former receive dedicated education on issues like corruption and bribery. Non-law students, on the other hand, may view corruption as a victimless crime (Wertheimer, 1977), which may appear to have less severity than handling stolen goods with knowledge.

In the scenario presenting a bank's overcharging of its customers and the handling of stolen goods, $43 \%$ of the respondents view both crimes as equally serious ( $\overline{\mathrm{x}} 0.25)$. As a possible explanation, one may put forward the idea proposed above, that in both crimes, the offender earns ill-gotten gains. Another possible explanation for the assignment of an equal degree of seriousness to these crimes could be the current issues, such as bank fraud, that many people suffer in Azerbaijan. Indeed, a content analysis by a local research agency - Media Monitoring Center for one month (July 2016) identified 285 cases of news reports on bank frauds within a single month alone (Sputnik News Agency, 2016). Among these 285 reports, at least 113 of them were on fraud by a bank against a customer. Thus, it is possible that the respondents, aware of the potential repercussions of bank fraud both for customer and financial system (i.e. undermining trust in the system), view this particular white-collar offence more seriously.

In the comparison of handling stolen goods and manipulation of the stock price in the stock market, the proportion of respondents regarding the two crimes as equally serious was nearly the same as the proportion who viewed the white-collar crimes as more serious than the ordinary crime $(0.23)$. This finding was relatively unexpected, given that manipulation of the stock price is comparatively less known in Azerbaijan's context largely due to the significantly smaller size and nascent nature of the stock market, as well as the absence of related offences such as manipulation of a stock price, at least in official statistics. The stock market in Azerbaijan has been established in the early 2000s and at the time of the writing, there were 29 publicly listed companies (Baku Stock Exchange, 2019). A search of databases of news websites in Azerbaijan for manipulation of the stock price in the stock market by an investment firm generates no results, and 
the official data on crime contains no information on this particular financial crime either. Thus, the activities in the stock market are not well known among many people. Nonetheless, the fact that $37 \%$ of the students perceive manipulation of the stock price as equally serious as the handling of stolen goods indicates that some respondents probably had a certain level of knowledge of the manipulation of stock price and its potential repercussions (i.e. undermining of trust in financial markets, a loss for investors) for the stock market, the economy, and the investment community in general. It is highly possible that these students may have obtained the relevant knowledge from the media. Moreover, respondents may perceive these acts as equally serious because in both cases the offender earns ill-gotten gains. However, there was a difference between the responses of law and criminology and non-law students in this scenario. That is, more law and criminology students view white-collar offence more serious than the street crime it was compared against. This difference may be attributed to the better knowledge of law and criminology students of the severity of manipulation of stock prices, which may not be well known among other groups of students. Interestingly, more non-urban dwellers attached more seriousness towards the manipulation of the stock price in the stock market than their counterparts in urban areas. The exact nature of the relationships observed remains obscure and warrant further research.

It is worth reviewing the proportion of the respondents victimised by white-collar crime, since it may provide further explanation for the assignment of a generally higher degree of seriousness to these crimes presented in the scenarios. The fact that $32 \%$ of the students or someone in their household suffered from the consequences of a large corporate crime or scandal in the last 12 months may be interpreted as a plausible explanation as to why they tend to see white-collar crimes more seriously than ordinary crimes. A relatively higher proportion of the students (54\%) indicated their victimisation as a result of pricing fraud in the last 12 months, which may also feed strong condemnation of the crimes committed by white-collar employees.

Finally, according to the Mann-Whitney U test, none of the demographic characteristics - age, gender, and household income were found to have a significant influence on perceptions of the seriousness of crimes presented.

This study's findings somewhat extend the current knowledge on public perception of white-collar crimes by covering a population unstudied hitherto. The findings generally conform to the previous studies covered above (Calavita, Pontell and Tillman, 1997; Kane \& Wall, 2006; Piquero, Carmichael, \& Piquero, 2007; Dodge, Bosick \& 
Antwerp, 2013; Sever and Roth, 2012) in the sense that white-collar crimes were perceived either equally or more serious than traditional crimes by the students surveyed by the current study, though we acknowledge the methodological differences between this and other studies. Thus, this study could be said to have been more an addition to the existing stock of knowledge on public perception of white-collar crimes than a development of new theoretical strand.

\section{Limitations and Suggestions for Further Research}

There are a number of limitations to this study. First, only university students of a few courses of one university in an urban area were recruited. Not only did such a sample cover a very small proportion of the overall student body at the university, but these students were educated in their respective fields, which can have implications for the representativeness of the sample. That is, the views of educated people may differ from those without education at all. It is also worth noting that the number of students from law and criminology and other faculties were not similar. Furthermore, students residing in an urban area, where many forms of white-collar crimes occur more frequently and are discussed more extensively than in rural regions, may have different attitudes towards this category of crime than their rural counterparts. Considering the sample-related issues, the authors strongly suggest further studies be conducted across a nationally representative sample in order to gauge Azerbaijani public's perception of crimes more accurately and comprehensively. Another limitation is that, as is the case with most public perception surveys, the current study attempted to explore the crime seriousness ratings of only certain types of crimes in Azerbaijan. In other words, not all types of crimes were included in the survey. The surveys in the future could include a wider list of crimes. Methodologically, this study did not present a violent street crime. As noted and demonstrated by Michel (2015) comparisons involving a violent street crime could have led to lower perceived seriousness for the white-collar crimes. Therefore, future research could make a direct comparison between violent and non-violent crimes.

\footnotetext{
Peer-review: Externally peer-reviewed.

Conflict of Interest: The authors have no conflict of interest to declare.

Grant Support: The authors declared that this study has received no financial support.

Hakem Değerlendirmesi: Dış bağımsız.

Çıkar Çatışması: Yazarlar çıkar çatışması bildirmemiştir.

Finansal Destek: Yazarlar bu çalışma için finansal destek almadığını beyan etmiştir.
} 


\section{References/Kaynakça}

Albanese, J. S. (1995). White-collar crime in America. Englewood Cliffs, NJ: Prentice Hall.

Baku Stock Exchange (2019) Milestones in BSE’s history. Retrieved from: https://bfb.az/eng/tarixce/

Benk, Serkan, McGee, Robert W., Budak, Tamer. (2018) A public perception study on bribery as a crime in Turkey. Journal of Financial Crime, 25(2), 337-353. doi:10.1108/JFC-07-2017-0061

Benson, L.M., \& Simpson, S.S. (2014) Understanding White-Collar Crime: An Opportunity Perspective. USA, Routledge

Bertelsman Stiftung (2018). BTI 2018 | Azerbaijan Country Report. Retrieved from: https://www.bti-project.org/ de/berichte/laenderberichte/detail/itc/AZE/

Calavita, K., Pontell, H., \& Tillman, R. (1997). Big money crime: Fraud and politics in the $S$ \& L crisis. Irvine: University of California Press.

Carroll, R.M, Pine, S.P, Cline, S.J. and Kleinhans, B.R. (1974) Judged Seriousness of Watergate-Related Crimes, Journal of Psychology, 86, 235-39. doi: https://doi.org/10.1080/00223980.1974.9924822

Côté, I. (2013). Fieldwork in the era of social media: Opportunities and challenges. PS: Political Science \& Politics, 46, 615-619.

Council of Europe (2019) Azerbaijan should ease the pressure on free speech, improve the situation of lawyers and continue to work towards better livelihood opportunities for IDPs. https://www.coe.int/en/web/ commissioner/-/azerbaijan-should-ease-the-pressure-on-free-speech-improve-the-situation-of-lawyers-andcontinue-to-work-towards-better-livelihood-opportunities-for-i

Croall, H. (2001). Understanding white collar crime. Buckingham, UK: Open University Press.

Cullen, F. T., Clark, G. A., Mathers, R. A., \& Cullen, J. B. (1983). Public support for punishing white-collar crime: Blaming the victim revisited? Journal of Criminal Justice, 11, 481-493. doi: 10.1016/00472352(83)90002-8

Cullen, F. T., Clark, G. A., Link, B. G., Mathers, R. A., Niedospial, J. E., \& Sheahan, M. (1985). Dissecting white-collar crime: offence type and punitiveness. International Journal of Comparative and Applied Criminal Justice, 9, 15-28.

Cullen, F. T., Hartman, L.J., \& Jonson, L.C. (2009). Bad guys: Why the public supports punishing white-collar offenders. Crime Law and Social Change 51(1):31-44

de Waal, T. (2013). Black Garden: Armenia and Azerbaijan through Peace and War. New York, New York University Press

Dodge, M., Bosick, S. J., \& Antwerp, V. V. (2013). Do Men and Women Perceive White-Collar and Street Crime Differently? Exploring Gender Differences in the Perception of Seriousness, Motives, and Punishment. Journal of Contemporary Criminal Justice, 29(3), 399-415. doi.org/10.1177\%2F1043986213496378

Farnworth, M., Longmire, D. R., and West, V. M. (1998) ‘College students' views on criminal justice,' Journal of Criminal Justice Education, 9 (1): 39-57. doi.org/10.1080/10511259800084171

Ferraro, K. \& Lagrange R. (1985). The measurement of fear of crime. Sociological Inquiry, 57. https://doi. org/10.1111/j.1475-682X.1987.tb01181.x

Friedrichs, D. O. (1996). Trusted criminals: White collar crime in contemporary society. Belmont: Wadsworth Pub. Co.

Friedrichs, D. O. (2007). Trusted criminals: White-collar crime in contemporary society (3rd ed.). Belmont, CA: Wadsworth Thompson.

Geis, G. (1973). Deterring corporate crime. In R. Nader \& M. J. Greed (Eds.), Corporate power in America (pp. 182-197). New York: Grossman.

Goff, C., \& Nason-Clark, N. (1989). The seriousness of crime in Frederickton, New Brunswick: perception towards white collar crime. Canadian Journal of Criminology, 31, 19-34. doi.org/10.1177\%2F0011128707303623

Goldstein, H. (1974). Police corruption: A perspective on its nature and control. Washington, DC: Police Foundation. 
Grabowsky, P. N., Braithwaite, J. B., \& Wilson, P. R. (1987). The myth of community tolerance toward whitecollar crime. Australian and New Zealand Journal of Criminology, 20, 33-44. doi.org/10.1177\% 2F000486588702000104

Hamilton, V., \& Sanders, J. (1996). Corporate Crime through Citizens' Eyes: Stratification and Responsibility in the United States, Russia, and Japan. Law \& Society Review, 30(3), 513-547. doi/10.2307/3054127

Healy, P.M. \& Serafeim, G (2016). An Analysis of Firms' Self-Reported Anticorruption Efforts. The Accounting Review: 91(2), 489-511. doi.org/10.2139/ssrn.2229039

Holtfreter, K. (2005). Is occupational fraud "typical" white-collar crime? A comparison of individual and organizational characteristics. Journal of Criminal Justice, 33, 353-365. doi.org/10.1016/j.jcrimjus.2005.04.005

Huisman, W., \& Vande Walle, G. (2010). The criminology of corruption. In G. de Graaf, P. von Maravic, \& P. Waagenar (Eds.), The good cause. Theoretical perspectives on corruption (pp. 115-145). London: Barbara Budrich Publishers.

Isenring, L.G. (2008). Perception of Seriousness and Concern about White-Collar Crime: Some Results of an Opinion Survey Among Swiss Banks. European Journal of Criminal Policy and Research, 14:371-389

Kane, J., \& Wall, A. D. (2006). The 2005 National Public Survey on White Collar Crime. Fairmont: National White Collar Crime Center.is:pi:

Kelly, D., Harper, D. J., \& Landau, B. (2008). Questionnaire mode effects in interactive information retrieval experiments. Information Processing and Management, 44(1), 122-141. doi.org/10.1016/j.ipm.2007.02.007

Kennedy, J.P. (2010). Examining the impact of ethics education on business students' perceptions of white- collar crime. Digital Commons at Wayne State University

Lee, JK., Frank, H., Wadsworth, J.W., \& Brenda, S. (2017) Corruption Perceptions in the Caucasus: Impediments to Business Activity in Armenia, Azerbaijan, and Georgia. Journal of Marketing Management, 5 (2) 22-30

Martinez, J. P. (2014). Unpunished criminals: the social acceptability of white collar crimes in America (Unpublished senior honors thesis). Eastern Michigan University, Ypsilanti, MI.

Meier, R. F., \& Short, J. F. (1985). Crime as a hazard: Perceptions of risk and seriousness. Criminology, 23, 389-399. doi.org/10.1111/j.1745-9125.1985.tb00346.x

Michel, C. (2017) Examining the Influence of Increased Knowledge About White-Collar Crime on Attitudes Toward It in the Undergraduate Classroom. Journal of Criminal Justice Education, 28(1), 52-73. https:// doi.org/10.1080/10511253.2016.1165854

Michel, C. (2015) Violent Street Crime Versus Harmful White-Collar Crime: A Comparison of Perceived Seriousness and Punitiveness. Critical Criminology, 24:127-143

Nelken, D. (2002). White collar crime. In: Maguire, Mike, Morgan, Rod and Reiner, Robert eds. The Oxford Handbook of Criminology (3rd ed.), Oxford: Oxford University Press, pp. 844-877.

Organisation for Economic Co-operation and Development. (2016). Anti-corruption reforms in Azerbaijan: Fourth round of monitoring of the Istanbul Anti-Corruption Action Plan. http:/www.oecd.org/corruption/ anti-bribery/OECD-ACN-Azerbaijan-Round-4-Monitoring-Report-ENG.pdf

Papiashvili, T., \& Orugova, L. (2013). Challenges of Azerbaijan pharmacy market development: Affordability of the prices an issue for local patients. Journal of Business (IBSUJB), 2(1), 21-24.

Piquero, N. L., Carmichael, S., \& Piquero, A. R. (2007). Research note: Assessing the perceived seriousness of white-collar and street crime. Crime \& Delinquency, 54, 1-22. doi:org/10.1177\%2F0011128707303623

Pontell, H., \& Geis, G. (2007). Black mist and white collars: Economic crime in the United States and Japan. Asian Criminology, 2, 111-126. doi:10.1007/s11417-007-9032-1

Rosoff, S., Pontell, H., \& Tillman, R. (2010). Profit without honor: White collar crime and the looting of America. Saddle River, Pearson.

Rossi, P. H., Waite, E., Bose, C. E., \& Berk, R. E. (1974). The seriousness of crimes: Normative structure and individual differences. American Sociological Review, 39, 224-237. doi:10.2307/2094234 
Sadigov, T. (2014). Corruption and social responsibility: Bribe offers among small entrepreneurs in Azerbaijan. East European Politics, 30(1), 34-53. doi:10.1080/21599165.2013.861351

Sadigov, T. (2018). Psychological dimension of corruption: How are citizens likely to support anti-corruption policies in Azerbaijan? International Journal of Sociology and Social Policy, 38(5-6), 484-508. doi:10.1108/ IJSSP-10-2017-0133

Sebba, L. (1983). Attitudes of new immigrants toward white-collar crime: a cross-cultural exploration. Human Relations, 35(12), 1091-1110. doi/10.1177/001872678303601202

Sever, M. \& Roth, M.P (2012). Public Perceptions of White-Collar Crime in Turkey and Some Comparisons with the United States. Asian Journal of Criminology, 7: 327, doi 10.1007/s11417-011-9121-z

Slapper, G., \& Tombs, S., (1999). Corporate Crime, London: Longman

Sputnik News Agency (2016) Azərbaycanda əhalinin ən çox narazılığına səbəb olan bank [The bank with the largest amount of complaints in Azerbaijan. Retrieved from: https://sputnik.az/life/20160701/406020155. html

State Statistics Committee (2018). Crime data. Retrieved from: https:/www.stat.gov.az/source/crimes/

Sutherland, E. H. (1940). White-collar criminality. American Sociological Review, 5(1), 1-12.

Sutherland, E. H. (1983). White Collar Crime - The Uncut Version. New Haven, Yale University Press

The Economist (2019) Democracy Index 2019. https://www.eiu.com/topic/democracy-index

The Institute for War \& Peace Reporting (2016). Azerbaijan's Flawed Healthcare System. Retrieved from: https:// iwpr.net/global-voices/azerbaijans-flawed-healthcare-system

Transparency International (2019) Azerbaijan. https://www.transparency.org/en/countries/azerbaijan

Transparency International (2018). Corruption perceptions index (CPI). Retrieved from https://www.transparency. org/cpi2018

United Nations Development Programme (2018). Human Development Indices and Indicators: 2018 Statistical Update. http://hdr.undp.org/sites/default/files/Country-Profiles/AZE.pdf Accessed 13 September 2019

US State Department. (2017). Azerbaijan 2017 human rights report. Retrieved from: https://www.state.gov/ documents/organization/277385.pdf

van Erp, J., Huisman, W. and Vande Walle, G (2015). The Routledge Handbook of White-Collar and Corporate Crime in Europe. UK, Routledge

Wertheimer, A. (1977). Victimless Crimes. Ethics, 87(4), 302-318.

The World Bank (2018) Azerbaijan. Accessed 11 September 2019 Retrieved from: https://data.worldbank.org/ country/azerbaijan. 
